\title{
Mateusz Kostro
}

University of Białystok

kostro.mateusz@gmail.com

\section{The Participation of a Social Factor in the Administration of Justice as the Implementation of the Rule of the Public Trial}

\begin{abstract}
The article presents the rule of transparency in criminal procedure, especially the external aspect of this rule - the rule of a public trial. The paper shows constitutional and criminal regulations of the rule of an open trial. The article presents when a trial is freely accessible for the audience and when an open trial is not possible. What is more, the article depicts targets, features and aspects of the implementation of the rule of an open trial.
\end{abstract}

Keywords: criminal procedure, social factor, rule, audience, transparency

\section{Introduction}

The participation of social factor in the administration of justice is one of the fundamental principles of the justice system operation regulated by the Polish legislator. It has been enshrined in the most important legal act - the Constitution of the Republic of Poland of 2 April $1997^{1}$ in Art. 45 and 182. For the needs of the article, two possible types of the participation of citizenry in the administration of justice should be distinguished:

- through the assumed role in the proceedings (participation sensu stricto);

- through the presence in a courtroom without assuming any role in the proceedings (participation sensu largo).

With regard to concrete forms of the participation of social factor in the administration of justices, the following three examples can be depicted:

- participation of lay judges in sentencing;

- the institution of a community representative; 
- public access to open and public hearings.

Within the narrow meaning of the word, the participation of social factor mostly refers to court benches composed of lay judges and the institution of a community representative. The broad meaning of the participation of citizenry in the administration of justice, on the other hand, should be understood as public access to open and public hearings.

\section{Participation of social factor sensu largo}

\subsection{General comments}

Active community participation in the administration of justice, which entails taking a specified role in litigation, is not the only manifestation of the participation of social factor. Apart from the constitutional principle contained in Art. 182 of the Constitution, another equally important principle of an open trial envisaged in Art. 45 of the Constitution should be mentioned. It is one of the pillars of the rule of a fair trial functioning in democratic states.

The rule of an open and public trial has been permanently embedded in the development of criminal procedure. The rule of a public trial, which was unlimited with regard to the parties and audience, was binding already in the Roman criminal trial. It was favoured, among others, by the very venues where the proceedings were held - market squares, and during the Republic - court buildings (basilicae) ${ }^{2}$. In the Athenian democracy, the principle of an open trial was an indispensible element of a court as well; it was already understood as internal and external openness ${ }^{3}$. During the Early Middle Ages in Poland, the princely court in assemblies was, among others, open and public. It was usually held in the open air and was attended by a large number of audience. The inquisitorial trial, on the other hand, was secret. In the Noble Republic of Poland, a distinct form of a criminal trial developed in city courts under the influence of Constitutio Criminalis Carolina. The reception, however, was not full; contrary to German proceedings, a trial was open and public ${ }^{4}$. In the 19th century trial, the mixed court developed, which retained elements of the inquisitorial court (most of all in preparatory proceedings). A main hearing was held according to the principle of both external and internal openness ${ }^{5}$. As far as Polish interwar legislation is concerned, the Act of 17 March 1921 - the Constitution of the Republic of Poland ${ }^{6}$, already stipulated that both civil and criminal trials are open and public unless an ex-

\footnotetext{
2 J. Skorupka, Jawność procesu karnego w toku jego historycznych zmian, (in:) J. Skorupka (ed.), Jawność procesu karnego, Warszawa 2012, p. 29. K. Nowicki, Jawność zewnętrzna postępowania sądowego, (in:) J. Skorupka (ed.), Jawność procesu karnego, Warszawa 2012, p. 311 
The Participation of a Social Factor in the Administration of Justice...

ception thereto is envisaged. Regulation of President of the Republic of Poland of 19 March 1928 - The Code of Criminal Procedure ${ }^{7}$, was issued in a similar vein. Pursuant to Art. 315 of the CCP of 1928, a hearing was held orally and openly, with some exceptions envisaged in the Act. Post-war legislation referred to the rule of an open trial too. The Constitution of $1952^{8}$ contained a provision in Art. 53 par. 1, according to which cases are resolved openly and publicly in all courts of the Polish People's Republic. In the 1950s, show trials were held outside court buildings, most of all in cases involving theft of public property and in political trials. This method was still used as late as in the end of the $1980 \mathrm{~s}^{9}$. The rule of an open and public trial (with specified exceptions) was appropriately included in the Code of Criminal Procedure of 1969.

The very notion of open and public proceedings can be understood in two ways:

- as internal openness;

- as external openness.

Internal openness should be understood as a principle referring solely to the litigation parties and individuals cooperating with them. It is a guarantee of adversarial proceedings. Its core are the parties' rights to access case files and participate in evidence-gathering acts. The participation of the parties (or individuals cooperating with them) will be full only if they are provided with unrestricted access to all information and acts connected with the litigation. In this aspect, the principle of an open trial is closely connected with the principle of the right to a court and a fair trial.

It has been rightly noticed that external openness should be treated as a separate rule - the rule of an open and public trial ${ }^{10}$ referring to the entire society. And just this rule is regulated by Art. 45 par. 1 of the Constitution. An open and public trial is not understood by the Constitution as internal openness because it is embraced by the rule of a fair trial ${ }^{11}$. Thus it involves open proceedings with regard to third parties (including the media).

Open proceedings resolving a case encompass:

- open and public court sessions;

- broadly understood open and public litigation, which should be understood as a possibility of obtaining information about the course of proceedings by third parties and public opinion;

- publicly announced judgment.

Journal of Laws of 1932, No. 83, item 725 as amended.

Journal of Laws No. 33, item 232 as amended.

B. Wójcicka, Jawność postępowania sądowego w polskim procesie karnym, Łódź 1989, p. 125.

P. Hofmański, O jawności posiedzeń sądowych, (in:) A. Marek (ed.), Współczesne problemy procesu karnego i jego efektywności, Toruń 2004, p. 12-121.

11 Judgment of Constitutional Tribunal of 11 June 2002, SK 5/02, OTK-A 2002, No. 4, item 41. 


\subsection{System regulation}

The Constitution does not indicate what sessions should be open and public. It means that all sessions, as a rule, are held openly and publicly regardless of the type of proceedings: first-instance, appeal or cassation. It is a standard procedure that cases should be resolved in a manner allowing audience to participate therein. Case settlement should be publicly announced. The constitutional legislator uses the notion of a judgment, which should be understood as a substantive ruling passed in individual proceedings. It obviously does not refer to rulings that do not concern the subject of litigation (e.g. discontinuance of proceedings), or rulings on incidental issues (e.g. restitution of a prior status - restitutio in integrum $)^{12}$. A publicly announced ruling should be understood as both reading the sentence and providing essential reasoning thereto in an open session after terminated proceedings and providing third parties with public access to the ruling in a court building, or including its content in the collection of judicial decisions ${ }^{13}$. The requirement of a public announcement of a judgment must be paid attention to. Although a trial may be held in secret, the ruling should always be made public. It proves great significance of the principle of an open trial. The legislator stresses with much emphasis transparency of state bodies' activity. The rule of an open trial should be applied as broadly as possible until it does not contradict other interests or values.

Furthermore, Art. 45 par. 2 of the Constitution regulates reasons for the exclusion of an open trial. They embrace: morality, State security, public order or protection of the private life of a party, or other important private interest. It was necessary to regulate situations where the rule of an open trial yields precedence to other values as it may often happen that openness will contradict private or public interest. Then, exceptionally, the rule of an open trial should be abandoned in favour of the higher or greater good.

It should be mentioned that the rule of an open trial has also been regulated in international acts of law. Art. 6 par. 1 of the European Convention on Human Rights ${ }^{14}$ clearly indicates that courts proceedings are open but the press and public may be excluded from all or part of the trial in the interest of morals, public order or national security in a democratic society, where the interests of juveniles or the protection of the private life of the parties so require, or the extent strictly necessary in the opinion of the court in special circumstances where publicity would prejudice the interests of justice. It is a very similar regulation to the one contained in the Constitution of the Republic of Poland. The fact that both present and previous European legislation has

P. Grzegorczyk, K. Weitz, (in:) M. Safjan, L. Bosek (ed.), Konstytucja RP, Tom I, Warszawa 2016, p. 1143. Ibidem, s. 1143.

Convention on the Protection of Human Rights and Fundamental Freedoms drafted in Rome on 4 November 1950, amended by Protocol No. 3, 5 and 8 and supplemented by Protocol No. 2 (Journal of Laws of 1993 No. 61, item 284). 
The Participation of a Social Factor in the Administration of Justice...

put such great emphasis on this rule proves its considerable importance and deeprooted origin in the European legal culture.

\subsection{Regulation of the Code of Criminal Procedure}

In the criminal procedure, an open main hearing has been regulated in Chapter 42 of the Code of Criminal Procedure. Art. 355 of the CCP envisages that a hearing, in principle, is open and public but there may be exceptions from this principle (the Code of Criminal Procedure itself envisages such cases as well as other Acts, e.g. the Act of 25 June 1997 on the Crown Witness ${ }^{15}$ ). A necessary element for the principle of an open trial to be implemented is to provide access to the information about a venue and time of a hearing so that interested parties may take part in it. As indicated by the European Court of Human Rights, factual obstacles hampering the implementation of the principle of an open trial result in the violation of the European Convention on Human Rights ${ }^{16}$. The rule of an open and public trial obviously does not refer to all proceedings since Art. $108 \$ 1$ of the CCP stipulates that the deliberation and voting on the decision shall be conducted in a closed session. With regard to the exclusion of openness, it shall not be allowed when judgment is announced (Art. 45 par. 2 of the Constitution). Opposite to a hearing, a session is secret (Art. 95b of the CCP) even though the legislator has also introduced exceptions from this rule. A session may be open if it is specified accordingly by the Act (the catalogue from Art. 95b $\$ 2$ of the $\mathrm{CCP}$ ) and when the Court President or court rules otherwise. The Act imposes an obligation to carry out an open session when the defendant's criminal liability is to be decided thereon. Such sessions concern: discontinuance of proceedings (Art. 339 $\$ 3$ point 1 and 2 of the CCP), a conditional suspension of the proceedings (Art. 339 $\$ 3$ point 5 of the CCP), conditional discontinuance of proceedings (Art. 341 of the $\mathrm{CCP}$ ), a sentence without a trial (Art. $343 \S 5$ of the CCP), a sentence without evidentiary proceedings (Art. 343a of the CCP), extradition (Art. 603 of the CCP), transfer and custody (Art. $6071 \S 1$ of the CCP), execution of punishment or measure in case of refusal to transfer (Art. 607s $\$ 3$ of the CCP), and transfer and judgment execution (611c $\$ 4$ of the CCP, 611 ti $\$ 1$ of the CCP). As rightly observed by H. Paluszkiewicz ${ }^{17}$, admitting to a session other persons than the participants of litigation in the above situations fulfils the standard of public proceedings. Community has an opportunity to find out about the court's decision on the defendant's criminal liability, the content of a judgment and its reasoning.

It is worth paying attention here to Art. 418a of the CCP, according to which if a judgment was rendered in a secret session, the content of the judgment shall be made public by submitting its copy in the court's secretary office for a seven-day

Uniform text: Journal of Laws of 2014, item 1801 as amended.

Judgment of ECHR of 14 November 2000 in the case of Riepan v. Austria, No. of complaint 35115/97, § 27.

$\mathrm{H}$. Paluszkiewicz, Pierwszoinstancyjne wyrokowanie merytoryczne poza rozprawą w polskim procesie karnym, Warszawa 2008, p. 268. 
period. At the same time, the Supreme Administrative Court noticed that a court's judgment is an official document in the meaning of the Act on Access to Public Information and does not lose this character after it has been publicly announced or made public in a court's secretary office ${ }^{18}$. Furthermore, the Polish Constitution stipulates that each citizen shall have the right to obtain information on the activities of organs of public authority (Art. 61 of the Constitution). It shows that a purpose of both the legislator and bodies applying the law is the assurance of transparency of the activities of bodies of public authority. In this context, anonymization of rulings, which is discernible, e.g., in the Lex portal, is puzzling. It is depicted that in West European countries and the USA rulings posted in Internet portals are not subject to such anonymization. For instance, the ECHR decisions give the parties' names and surnames ${ }^{19}$. It should also be mentioned that the party may apply for decision's anonymization, which ECHR often accepts. Undeniably, Internet access to the full content of rulings would enhance community supervision and trust in the administration of justice. This issue is debatable and thus worth mentioning herein.

If pending proceedings attract considerable interest which would be beyond the court's organizational capacities, entry passes may be issued to a court room. This right is vested in the Court President ${ }^{20}$. It may not, however, ensue a selection of persons admitted to participate in a hearing as audience even though entry passes may first be granted to the media representatives, individuals connected with the litigation parties, or persons interested in the proceedings for scientific reasons ${ }^{21}$. A selection of persons admitted to a court room would apparently contradict the principle of an open and public trial. It could entail the admittance of persons favouring solely one party to the proceedings, or hostile to a witness thus evoking certain anxiety in him or her. It seems that the only case of a broadly understood selection may the situation regulated in Art. 359 of the CCP.

Art. 359 of the CCP indicates that the principle of an open and public trial is not tantamount to the full openness of a trial to everyone. $\$ 1$ thereof univocally sets forth that apart from the participants of the proceeding, a hearing may be solely attended by individuals who have come of age and are unarmed. This ban may be reversed by an order of the presiding judge. As far as minors are concerned, their presence in a trial may be justified by their relations or ties with a party thereto or educational reasons $\mathrm{s}^{22}$. With regard to armed individuals, the presiding judge may permit them to attend a trial if they are obliged to carry weapons. What is more, persons

Judgment of Supreme Administrative Court of 11 August 2011, I OSK 933/11, Lex No. 1165432.

See: P. Dobrowolski, Jawność postępowań: wszystko, co dzieje się na sali sądowej, jest wspólną sprawą, "Dziennik Gazeta Prawna" of 20 January 2012, http://prawo.gazetaprawna.pl/artykuly/586201,jawnosc-postepowan-wszystko-co-sie-dzieje-na-sali-sadowej-jest-wspolna-sprawa.html.

$\S 68$ of the Regulation of Minister of Justice of 23 December 2015. Regulation of Common Courts Official Activity (Journal of Law, item 2316 as amended).

W. Jasiński, (in:) J. Skorupka (ed.), Kodeks postępowania karnego. Komentarz, Warszawa 2016, p. 881. Ibidem, p. 880. 
The Participation of a Social Factor in the Administration of Justice...

in a condition incompatible with the court's dignity shall not be admitted to the trial. It concerns, most of all, people under the influence of alcohol or drugs, or individuals whose conduct or dress is inappropriate.

With the current development of technology, an indispensible element of the principle of open proceedings is the presence of the media in a trial. Art. $357 \$ 1$ of the CCP obliges the court to permit the representatives of the media to make video and sound recordings of the trial. It is worth adding that an application for such permit should be submitted by a representative of a specified medium; that is why the court acts upon the initiative of an applicant. This permit obviously concerns recording the trial by means of special equipment, i.e. a photo camera, sound recorder or video camera. A number of the media representatives in a trial may also be limited for technical conditions of a courtroom (the above mentioned issue of entry passes). In case of such restrictions, it is essential to maintain objectivity in choosing the media representatives. Paragraph 3 prescribes that the choice can be made on the first come first serve basis, or at random. If the course of a trial is disturbed by the media representatives, the court shall order them to leave a courtroom. The media may also be instructed to leave a courtroom if their presence embarrasses or confuses a witness. Then it is a temporary leave of a courtroom only for the time of hearing a witness. Therefore paragraph 4 assigns priority to the principle of substantial truth over the principle of an open trial $^{23}$ as it is more important to duly hear a witness than fulfil the principle of open proceedings. As noticed by R. Koper ${ }^{24}$, the issue of recording a trial has been well balanced by the legislator. Agreeability of the regulation contained in Art. 357 of the CCP is, in his opinion, very clear, creating solutions reconciling opposing interests and goods.

Another very important regulation is also worth considering, namely Art. 13 of the Act of 26 January 1984 - Press Law ${ }^{25}$. Paragraph 1 thereof sets forth that it is not allowed to express one's opinion about the settlement of litigation in the press before a judgment is in a first-instance court. It is of vital importance as it assures the observance of the principle of judicial independence, consideration for the defendant's interest (in the aspect of presumed innocence), and guarantees citizens' right to reliable information ${ }^{26}$. Furthermore, paragraph 2 of the provision in question stipulates that personal data and image of a person against whom preparatory proceedings or litigation is held must not be published in the press, as well as personal data and image of witnesses and injured parties, unless they give their consent. As far as the consent of the participants of proceedings is concerned, it is pointed out that the nature and

23 Ibidem, p. 883.

24 R. Koper, Jawność zewnętrzna postępowania karnego, (in:) W. Jasiński, K. Nowicki (ed.) Jawność jako wymóg rzetelnego procesu karnego. Zagadnienia prawa polskiego i obcego, Warszawa 2013, p. 112.

25 Journal of Laws No. 5, item 24 as amended.

26 R. Koper, Jawność..., op. cit., p. 112. 
scope of such consent cannot be presumed or alleged ${ }^{27}$. It should be univocal. On the other hand, the prosecutor or court may permit to disclose personal data and image of individuals against whom preparatory proceedings or litigation is held due to important public interest. This decision is subject to a complaint. It seems that such a solution allows to balance both private interest of the participants of a criminal trial and public interest. The Constitutional Tribunal ${ }^{28}$ ruled on the constitutionality of Art. 13 par. 3 of the Press Law because in its previous reading this provision did not envisage a possibility of submitting a complaint to a court against a decision of the prosecutor to permit the publication of data and image of participants of preparatory proceedings. The previous regulation was inconsistent with Art. 45 par. 1 and Art. 77 par. 2 of the Constitution of the Republic of Poland. In effect of the Constitutional Tribunal's judgment, par. 4 envisaging the above mentioned complaint was added to Art. 13 of the Press Law.

A party may apply to a court for a permit to record the course of a trial using sound recording equipment (Art. 358 of the CCP). The court may refuse only if it adversely affects the regularity of proceedings. Thus such a refusal should be treated as an exception.

The Code of Criminal Procedure provides two categories of cases that are closed to the public; when they regard:

- a motion from the state prosecutor for discontinuance of the proceedings due to the non-accountability of the perpetrator and application of a precautionary measure;

- a case of defamation or calumny; however, on a motion of the injured party, the hearing is held in open court.

These are the categories of cases that are fully closed to the public ex lege. With regard to cases of defamation or calumny, if the injured party submits a motion for an open trial, it is fully open to the public ex lege. The court may not disregard such a motion. The reason for such a solution is the implementation of the provision of Art. 45 par. 2 of the Constitution, which enshrines important private interest as the cause of excluded openness of proceedings.

Art. $360 \$ 1$ of the CCP establishes a possibility of excluding the public from all or part of the trial, where the public nature of a hearing may:

- be conducive to disturbance of public order,

- offend decency,

- disclose circumstances which in consideration of significant State interests should remain secret,

- infringe important private interests.

28 Judgment of Constitutional Tribunal of 18 July 2011, K 25/09, OTK-A 2011, No. 6, item 57. 
Moreover, the court may exclude the public from a hearing if at least one of the accused is a minor, for the time of hearing a witness who has not turned 15 years old, and upon a motion of a person who filed for prosecution. It is another situation when the CCP refers directly to Art. 45 par. 2 of the Constitution. The reasons listed in Art. $360 \$ 1$ of the CCP correspond to those envisaged in the Constitution. A practical example of the application of Art. $360 \$ 1$ of the CCP may be a hearing which was held on 24 November 2016 in the Regional Court in Białystok. The case involved the prosecution of Chechens accused of, among others, financial support given to the so called Islamic State. According to the media ${ }^{29}$, some witnesses giving evidence in this trial feared for their lives. Amidst them doctors who helped one of the defendants. Media coverage ensued that the court excluded the public from the trial due to confidentiality of medical information and witnesses fearing for their safety. It may be presumed that the public was excluded from this case due to important private interest.

Pursuant to the reading of the provision in force since 5 August $2016^{30}$, Art. $360 \S$ 2 sets forth that the prosecutor may object to the exclusion of the public from a hearing, which ensues its obligatory open pursuit. This objection may be raised only before the court issues a decision to exclude the public. In practice, before issuing a decision on the exclusion of the public from the proceedings, the court should request the prosecutor present in a trial to express his or her opinion on the exclusion of an open trial if the exclusion is grounded on Art. $360 \$ 1$ point 1 of the CCP. If the prosecutor objects to the exclusion of an open trial, the court is not allowed to exclude it. As pointed out in the literature ${ }^{31}$, it is a serious infringement of the principle of equality of litigants since only a prosecutor is entitled to object; the defendant does not enjoy such a right. In principle, the court is an entity which evaluates whether a specific value or interest may be a reason for the exclusion of the public from a hearing. In this case, the court's powers have been transferred onto the prosecutor. Moreover, the requirement of justifying the exclusion of the public if the prosecutor objects to it does not result from the content of the provision. Thus it can be claimed that the prosecutor enjoys greater discretion than the court since the court is obliged to justify its decision about the exclusion of the public while the prosecutor does not have to do so if he or she objects to the exclusion ${ }^{32}$. At the same time, a part of the doctrine points out that due to the maintenance of the right to defence by the participants of a criminal trial, prosecutor's objection should be supported by the reasoning and a possibility of appealing against it to the $\operatorname{court}^{33}$. 2016, http://www.poranny.pl/wiadomosci/Białystok/a/proces-podlaskich-czeczenow-swiadkowie-boja-sie--o-swoje-zycie,11495169/.

30 Act of 10 June 2016 on the Amendment of the Act - Code of Criminal Procedure, Act on the Profession of a Physician and Dentist and Act on Patient Rights and Patient Rights Ombudsman (Journal of Law, item 1070).

W. Jasiński, (in:) J. Skorupka (ed.), Kodeks..., op. cit., p. 888.

Ibidem, p. 888.

M. Zimna, Wyłączenie jawności rozprawy jako gwarancja ochrony interesów uczestników postępowania karnego, "Prokuratura i Prawo" 2016, No. 9, p. 99. 
Then, the catalogue of persons who may attend a hearing despite the exclusion of the public (Art. $361 \S 1$ of the CCP) should be provided. They are so called persons of trust. Apart from the litigants, they embrace: two persons designated by the public prosecutor, two by the auxiliary prosecutor, two by the private prosecutor and two by the defendant.

Persons of trust, however, cannot participate in a hearing if it is feared that confidential information classified as "secret" or "top secret" may be revealed. Additionally, persons of trust cannot participate in a hearing of a crown witness (Art. 13 par. 1 of the Act on the Crown Witness) and during reading incognito witness's testimony (Art. $393 \$ 4$ of the CCP). The presiding judge may permit individuals other than persons of trust to attend a closed hearing even if information classified as "secret" or "top secret" is revealed ${ }^{34}$.

The presiding judge shall inform the persons attending the hearing of their obligation to keep secret any information learned during the hearing in a closed session, and warn them of the consequences of their failure to do so (Art. 362 of the CCP). As indicated by the Supreme Court, "the Court is absolutely obliged [...] to carry out a hearing in such a manner [...] as not to allow any violation of legally protected interests of the injured parties" 35 .

If a motion is filed to have a hearing held in a closed session, and if the motion has been filed by the party or when the court finds it necessary, the hearing on the motion shall be conducted in a closed session (Art. 363 of the CCP).

Art. $364 \$ 1$ of the CCP prescribes that the judgement shall be announced in open court. It is another reference to the absolute rule of an open trial contained in the Constitution of the Republic of Poland (Art. par. 2 sentence 2 - The Judgments shall be announced publicly) and European Convention on Human Rights (Art. 6, item 1). However, if all or part of the trial has been held in a closed session, the announcement of the statement of reasons for the judgement may be also made in a closed session fully or partly.

\section{Conclusion}

The principle of open proceedings is one of the essential and oldest principles of litigation. With the development of technology, its range and scope have greatly increased. Previously, a number of individuals who could follow a specific trial was limited to those who found enough room in a public square or courtroom. Nowadays, the principle of an open trial refers rather to the recipients of the media, i.e. radio programme listeners, TV viewers, Internet users or readers. Open proceedings are

R.A. Stefański, (in:) R.A. Stefański, S. Zabłocki, Kodeks postępowania karnego. Komentarz, tom II, Warszawa 2004, p. 641.

Decision of Supreme Court of 25 March 2009, III KO 21/09, Lex No. 608111. 
now an institution thanks to which the community may learn about the operation of the administration of justice. Thus it exerts actual impact on the image of judges, prosecutors, attorneys and legal advisors. The principle of an open trial may be an effective instrument to build social trust in the administration of justice. Ipso facto, it should enhance the quality of work of judicial staff and raise legal awareness and culture of the citizens.

It should be remembered that judicial power is the only power citizens cannot directly affect at all. Opposite to legislative and executive power, judicial power is not elected by the people. Due to the principle of irremovability of judges, citizens cannot express their approval or disapproval towards the representatives of judicial power. Judge's independence, on the other hand, ensues not only a lack of citizens' impact on judicial power, but it also precludes other powers' impact on the administration of justice. Therefore the principle of an open trial is the only instrument allowing to exert control that is necessary to guarantee appropriate operation or work of every, even best educated and morally shaped entity. Such control is possible solely thanks to the access to information about the operation of judicial power that citizens are provided with. Information can only be obtained, in turn, if the external openness of proceedings is guaranteed. Lack of such information would evoke citizens distrust of the representatives of justice on the one hand, and negatively affect judges' motivation to carry out a proper service on the other hand. Activities of each power, including judicial power, are subject to the requirement of transparency. As ruled by the Constitutional Tribunal, a purpose of the principle of an open trial is to "assure judge's impartiality and regularity of proceedings, and motivate the court to employ greater diligence and conscientiousness in the proceedings" ${ }^{36}$.

Nevertheless, we should not forget that open proceedings must have certain limits. We should take into account circumstances that may arise in practice which would ensue the need to sacrifice the principle of an open trial for the sake of greater good. Such limits have been envisaged both by the Polish Constitution and Acts (including the Code of Criminal Procedure). Disclosure of information might imply serious infringement of private or public interests. We can easily imagine many situations where the presence of third parties, including the media, could threaten the above mentioned interests. It may be a business interest of an entrepreneur when his or her competitor is present in a courtroom while his or her business strategy is discussed or mentioned during a trial. A private interest may be wellbeing of a victim of a rape who filed for the prosecution. Violation of a public interest, in turn, may be a public hearing of a testimony given by a high rank officer of Internal Security Agency or Intelligence Service which could infringe a State secret, which is, ipso facto, the Republic of Poland's interest. We can imagine a situation when the subject of litigation is certain reprehensible conduct on the grounds of a race or worldview the public 
opinion is keenly debating. Then an open trial could evoke public nuisance. Finally, an open trial of the accused Minister where details of his or her private life are mentioned could infringe standards of public decency. Due to the above, it is necessary to protect goods and values which could be threatened in effect of open proceedings $s^{37}$.

As noticed by S. Waltos ${ }^{38}$, improper application of the principle of an open trial often adversely affects the principle of presumed innocence. We witness a recent phenomenon of conscious or intentional "leaks" of information from preparatory proceedings. It concerns both case files' photographs (publishing photos from the case files from preparatory proceedings in the so called "bug affair") and service officials making video recordings of suspects being detained. Such leaks are generally aimed at concrete persons or groups. Seeing an image of a handcuffed person, the public forms a negative opinion about this individual even though he or she is still innocent. Many a time, further acquittal does not change the opinion previously forged by the media coverage about the acquitted person. In such situations, the principle of presumed innocence simply does not work. Ensuing social pressure puts the court, defence counsel and, above all, the defendant, in a very difficult position.

Additionally, some attention should be paid to the transformation of traditional media (the press, television and the Internet) into modern social media. With regard to them, a role of a journalist and recipient mingles. In one place (portal), a recipient can be a journalist while a journalist - a recipient. It adversely affects the quality and manner of conveying information. It concerns both facts or opinions posted on Facebook or Tweeter as well video recordings uploaded in YouTube. It appears that within this area there are no binding principles except the principle of decency which is, nevertheless, excessively abused. At the same time, a range of social media is much broader than traditional ones. That is why a scale of abuses connected with publishing information about litigations is so vast.

The principle of open proceedings is enshrined by the Constitution of the Republic of Poland. It fulfils not only a system role but also assures regular and proper operation of the justice system by providing public access to its activities. This access is the only instrument affecting discipline and impartiality of the judiciary. This principle, however, cannot be abused in any way. It could adversely affect not only the image of the justice system but, above all, the image of private individuals. Regardless of the above, the principle of open proceedings is and should continue to be a fundamental pillar of a democratic state of law.

D. Gil, E. Kruk (ed.), Role uczestników postępowań sądowych - wczoraj, dziś i jutro, Tom II, Lublin 2015, p. 215. S. Waltoś, Domniemanie niewinności w świecie mediów, (in:) C. Kulesza (ed.), System wymiaru sprawiedliwości a media, Białystok 2009, p. 16-22. 


\section{BIBLIOGRAPHY}

Brzozowska-Pasieka M., Olszyński M., Pasieka J., Prawo prasowe. Komentarz, Warszawa 2013. Dobrowolski P., Jawność postępowań: wszystko, co dzieje się na sali sądowej, jest wspólną sprawą, "Dziennik Gazeta Prawna" z dnia 20 stycznia 2012 r., http://prawo.gazetaprawna.pl/arty- kuly/586201,jawnosc-postepowan-wszystko-co-sie-dzieje-na-sali-sadowej-jest-wspolna--sprawa. html.

Gil D., Kruk E. (eds.), Role uczestników postępowań sądowych - wczoraj, dziś i jutro, tom II, Lublin 2015.

Hofmański P., O jawności posiedzeń sądowych, (in:) A. Marek (ed.), Współczesne problemy procesu karnego i jego efektywności, Toruń 2004.

Koper R., Jawność zewnętrzna postępowania karnego, (in:) W. Jasiński, K. Nowicki (eds.), Jawność jako wymóg rzetelnego procesu karnego. Zagadnienia prawa polskiego i obcego, Warszawa 2013.

Krzewska I., Proces podlaskich Czeczenów. Świadkowie boją się o swoje życie, "Kurier Poranny" of 23 November 2016, http://www.poranny.pl/wiadomosci/bialystok/a/ proces-podlaskich-czeczenow-swiadkowie-boja-sie-o-swoje-zycie,11495169.

Nowicki K., Jawność zewnętrzna postępowania sądowego, (in:) J. Skorupka (ed.), Jawność procesu karnego, Warszawa 2012.

Paluszkiewicz H., Pierwszoinstancyjne wyrokowanie merytoryczne poza rozprawą w polskim procesie karnym, Warszawa 2008.

Safian M., Bosek L. (ed.), Konstytucja RP, tom I, Warszawa 2016.

Skorupka J. (ed.), Jawność procesu karnego, Warszawa 2012.

Skorupka J. (ed.), Kodeks postępowania karnego. Komentarz, Warszawa 2016.

Stefański R.A., Zabłocki S., Kodeks postępowania karnego. Komentarz, tom II, Warszawa 2004.

Waltoś S., Domniemanie niewinności w świecie mediów, (in:) C. Kulesza (ed.), System wymiaru sprawiedliwości a media, Białystok 2009.

Wójcicka B., Jawność Postępowania Sądowego w polskim procesie karnym, Łódź 1989.

Zimna M., Wyłączenie jawności rozprawy jako gwarancja ochrony interesów uczestników postępowania karnego, "Prokuratura i Prawo" 2016, No. 9. 